\title{
РАННІ УСКЛАДНЕННЯ ДЕКОРТИКАЦІї ЛЕГЕНІ У ХВОРИХ З НЕСПЕЦИФІЧНОЮ ЕМПІЕМОЮ ПЛЕВРИ: ПРИЧИНИ, МЕТОДИ ПРОФІЛАКТИКИ
}

\author{
В. В. Макаров, \\ доктор медичних наук, професор кафедри хірургї №1 Харківського національного медичного \\ університету, Україна \\ О. І. Цівенко, доктор медичних наук, професор кафедри хірургічних хвороб медичного \\ факультету Харківського національного університету імені В.Н. Каразіна, Украӥна
}

DOI: https://doi.org/10.31435/rsglobal_ws/30042020/7020

\begin{abstract}
ARTICLE INFO
Received: 19 February 2020

Accepted: 14 April 2020

Published: 30 April 2020

KEYWORDS

decortications of lung, complications.

ABSTRACT

We sorted out three groups of complications after perform an decortications of lung, developing in early post operational period: 1) the complications are caused by the technique of operations and anesthesia; 2) complications are caused by ineffective making of comprehensive treatment in post operational period; 3) combined complications. Making comprehensive treatment in preoperative and post operational period, making decortications of lung under visual control, making adequate ventilation during a time of operation, early sanitization of trachebronchialis tree and active patients after an operation, are measures of preventive complications by this patient group.
\end{abstract}

Citation: V.V. Makarov, O. I. Tsivenko. (2020) Early complications by patients with decortications of lung in empyema pleural: causes, methods of prevention. World Science. 4(56), Vol.1. doi: 10.31435/rsglobal_ws/30042020/7020

Copyright: (C) 2020 V.V. Makarov, O. I. Tsivenko. This is an open-access article distributed under the terms of the Creative Commons Attribution License (CC BY). The use, distribution or reproduction in other forums is permitted, provided the original author(s) or licensor are credited and that the original publication in this journal is cited, in accordance with accepted academic practice. No use, distribution or reproduction is permitted which does not comply with these terms.

Неспецифічна емпієма плеври залишається однією з актуальних проблем торакальної хірургії. Повсюдне зростання кількості гострих гнійних захворювань плеври багато авторів зв'язують з широким поширенням антибиотикорезистентної мікрофлори $[1,2,8,10]$. Змінився характер мікрофлори, що викликає розвиток гнійно-запального процесу, чутливість іiі до антибіотиків і інших лікарських засобів. З'явилися емпієми, що розвиваються внаслідок інфікування плеври флорою нечутливої або малочутливої до більшості антибіотиків. Усе це створює відомі труднощі у виборі найбільш ефективного способу лікування $[2,5,7]$.

Згідно $з$ даними вітчизняної та зарубіжної літератури неспецифічна емпієма плеври найчастіше зустрічаються у пацієнтів в терміни найбільшої трудової активності у віці від 28 до 60 років $[2,6,9]$. Незважаючи на накопичений досвід лікування хворих неспецифічною емпіємою плеври, тактика лікування цієї патології залишається предметом дискусії $[2,3,10]$. Ряд авторів віддає перевагу методу пункції лікування гострої емпієми плеври. $€$ прибічники малої хірургії - дренування плевральної порожнини 3 різними режимами аспірації відокремлюваного, використання етапних санацій плевральної порожнини під торакоскопічним контролем $[2,4,9]$.

Проте, кількість розвитку ригідних процесів в плевральній порожнині, перехід захворювання в хронічну форму не має тенденції до зменшення. Це пояснюється пізніми термінами госпіталізації пацієнтів, відсутністю спадкоємності в лікуванні хворих 3 цією патологією між терапевтичними стаціонарами і стаціонарами торакального профілю, тривалим знаходженням хворих з гострою емпіємою в загальнохірургічних стаціонарах, деструкцією легеневої тканини, розвитком бронхоплевральних свищів, недостатньою ефективністю 
лікування, що проводиться, на ранніх етапах захворювання $[2,6,9]$. Таким чином, декортикація легені зберігається в арсеналі лікування неспецифічної емпієми плеври. Попри те, що декортикація легені була запропонована Delorm у кінці XIX століття, особливості застосування цього оперативного втручання і сьогодні залишаються неоднозначні [2].

Досі немає одностайності у визначенні показань до операції і оптимальних термінів втручання $[2,4,6,9]$. Терміни проведення декортикації легені варіюють від 3 тижнів до 3 місяців. Перевага віддається більше раннім термінам проведення декортикації легені. При пізніших термінах існування емпієми плеври проведення декортикації легені вважається мало ефективною операцією, оскільки легеня втрачає здатність до розпрямлення [9]. Ряд авторів вказує на необхідність виконання операції тільки після попереднього дренування емпієми плеври і санації іiі порожнини антисептиками до досягнення "чистого" відокремлюваного. Інші дослідники пропонують не розкривати порожнину емпієми під час операції, видаляючи іiі "єдиним блоком". Оскільки іії розкриття призводить до поширення інфекції і рецидиву емпієми $[2,8]$. Що і пояснює, на наш погляд, значну кількість ускладнень після виконання декортикації легені у хворих з неспецифічною емпіємою плеври. За даними зарубіжних авторів кількість ускладнень варіюється від 10 до 28,5\%, і відзначається переважання ранніх ускладнень декортикації, що розвинулися в перші 10 діб післяопераційного періоду $[6,7,9]$. Готуючи хворого до виконання декортикації легені, слід враховувати, що емпієма плеври - це не місцевий, локальний процес, а захворювання, що призводить до порушення цілого ряду функцій органів і систем організму [2, 8]. Тому також важливим моментом в попередженні розвитку ускладнень після декортикації легені являється проведення адекватної передопераційної підготовки і комплексного лікування в післяопераційному періоді. Усе вище викладене стало основою для вивчення ускладнень, що найчастіше зустрічаються, після декортикації легені у хворих з неспецифічною емпіємою плеври і причин що привели до них.

Мета дослідження. Метою дослідження було вивчення ранніх ускладнень що зустрічаються після декортикації легені у хворих 3 неспецифічною емпіємою плеври і визначення методів їх профілактики.

Матеріали і методи дослідження. Нами вивчені результати лікування 86 хворих, що перенесли декортикацію легені з приводу неспецифічної емпієми плеври. Чоловіків було 72, жінок - 14. Вік хворих варіювався від 21 до 64 років. Ускладнення спостерігалися у 16 (18,6\%) хворих після виконання декортикації. Гостра внутрішньоплевральна кровотеча в післяопераційному періоді відзначалася у 2 пацієнтів. Неповне розпрямлення легені спостерігалося у 3 хворих. Гострий тромбоз підключичної вени спостерігався у 1 пацієнта, тромбоемболія дрібних гілок легеневої артерії на стороні виконання операції - 1 хворий. Ателектаз легені спостерігався у 2 пацієнтів. Гнійний бронхіт відзначався в післяопераційному періоді у 3 хворих. Запальнодеструктивні зміни легеневої тканини на стороні поразки -2 спостереження.

Нагноєння післяопераційної рани - 1 пацієнт, рецидив емпієми - 1 хворий.

Результати дослідження i їx обговорення. Розвиток ускладнень після виконання декортикації легені у хворих 3 неспецифічною емпіємою плеври залежав від термінів захворювання, технічних особливостей і травматичності втручання, вираженості склеротичних змін в легеневій тканині, адекватності проведення передопераційної підготовки і анестезії під час операції, ефективності дренування, комплексної терапії в післяопераційному періоді. При вивченні результатів лікування цієї групи хворих необхідно виділити необхідність адекватного дренування в післяопераційному періоді і використання різних режимів аспірації (ретроградного, переривчастого і так далі). Застосування системи активної аспірації сприяє розпрямленню легені, його фіксації до грудної стінки, $є$ профілактикою післяопераційних плевритів і гемотораксу.

Рентгенологічний контроль виконують в першу добу післяопераційного періоду, а далі через 2-3 доби, орієнтуючись на клінічну картину хворого. Якщо при контрольному рентгенологічному дослідженні виявився плевральний ексудат - виконувалися плевральні пункції. Характер плевральної рідини контролювався цитологічним методом, визначався зміст нейтрофільних лейкоцитів, проводилося бактеріологічне дослідження 3 визначенням чутливості виявлених мікроорганізмів до антибіотиків. При виявленні запальних змін з боку легеневої тканини проводили зміну антибактеріальної терапії. Антибактеріальна терапія проводилася антибіотиками широкого спектру дії або їх комбінацією з урахуванням чутливості виділеної мікрофлори. 
У післяопераційному періоді також проводили корекцію крововтрати під контролем показників червоної крові і порушень білкового і електролітного балансу. Проводилася профілактика тромбоемболічних ускладнень, загальнозміцнююча терапія. Адекватне знеболення в післяопераційному періоді є важливим компонентом комплексного лікування цієї групи хворих. При ефективному знеболенні можлива рання активізація хворих, що сприяє розпрямленню легені і $\epsilon$ профілактикою ускладнень обумовлених гіподинамією. 3 першого дня післяопераційного періоду проводилася лікувальна дихальна гімнастика, масаж грудної клітки, інгаляції, муколітична терапія, за показаннями виконувався дренаж положенням, робилася санаційна бронхоскопія. На 2-3 добу оперованих починали активізувати, що сприяло кращому розпрямленню легені.

Дренажні трубки видалялися в терміни від 2 діб до 25 діб. Послідовність видалення дренажів визначали індивідуально. За відсутності ексудату в плевральній порожнині першим видалявся нижній дренаж. Враховуючи частоту утворення залишкових порожнин, що локалізуються у верхніх відділах, ми не поспішали з видаленням верхнього дренажу. У умовах розпрямленні верхівки легені і припиненні функціонування верхнього дренажу робили його видалення через дві доби. За наявності ексудату в нижніх відділах плевральної порожнини і розпрямленні легені - першим видаляли верхній дренаж. Якщо відзначалася наявність осумкувань в плевральній порожнині, їх видаляли методом пункції.

Показаннями для видалення дренажних трубок було повне розпрямлення оперованої легені та припинення функціонування дренажів.

Рентгенологічний контроль тривав до виписки хворого із стаціонару.

Ускладнення, що розвинулися в ранньому післяопераційному періоді після декортикації легені, нами були розділені на наступні групи:

1) ускладнення, пов'язані з технікою проведення операції і наркозу;

2) ускладнення, пов'язані 3 неефективним проведенням комплексної терапії в післяопераційному періоді;

3) поєднані ускладнення.

До ускладнень, пов'язаних 3 технікою проведення операції декортикації легені і проведення анестезії нами віднесені випадки розвинутої внутрішньоплевральної кровотечі. У одному спостереженні кровотеча розвинулася 3 міжреберної артерії, в другому випадку 3 паренхіми легеневої тканини. Для профілактики цього ускладнення необхідно виконувати усі етапи декортикації під візуальним контролем. Застосовувати при виділенні легені сучасні інструментальні методики - різні варіанти коагуляції, біологічного зварювання. Контролювати гемостаз після виконання основних етапів операції. Для подальшого прогнозу важливо наскільки швидко ці ускладнення були розпізнані та усунені. У наших спостереженнях у обох хворих були виконані реторакотомії, гемостаз був досягнутий.

У наших спостереженнях були відсутні випадки розриву стравоходу при декортикації легені. Мірою профілактики розривів стравоходу при виконанні цих оперативних утручань $\epsilon$ встановлення шлункового зонду у оперованого хворого, з метою його кращої візуалізації. Ця маніпуляція вважається нами обов'язковою при виконанні декортикації легені. Розвиток гнійного бронхіту в одному спостереженні було викликано надходженням гнійного вмісту 3 плевральної порожнини в трахеобронхіальне дерево через бронхіальну норицю. Адекватна санація порожнини емпієми, постійна санація трахеобронхіального дерева під час проведення анестезії і ранньому післяопераційному періоді, застосування двопросвітної інтубації $\epsilon$ профілактичними заходами розвитку цього ускладнення. Для ліквідації цього ускладнення була застосована санаційна бронхоскопія, інгаляції, муколітична і антибактеріальна терапія.

Розвиток ателектазу легені у двох хворих, і виникнення гнійного бронхіту ми зв'язуємо 3 недоліками проведення анестезіологічного етапу. Для їх попередження необхідно використовувати в післяопераційному періоді санаційні бронхоскопії, ранню активізацію хворого, заходи які сприяють кращому відходженню мокроти (лікувальна фізкультура, масаж грудної клітки, інгаляції, постуральний дренаж і т. п.). Важливим інтраопераційним моментом $\epsilon$ адекватна вентиляція легені, початок санації трахеобронхіального дерева під час операції. Тромбоемболія дрібних гілок легеневої артерії на стороні виконання операції, відмічена у 1 хворого, пов'язана як 3 масивною операційною травмою, так і з порушеннями згортаючої системи крові. Для профілактики подібних ускладнень потрібне як зменшення травматичності 
операційного втручання, так i корекція наявних розладів згортаючої системи крові в доопераційному та післяопераційному періоді.

Неповне розпрямлення легені, яке спостерігалася у 3 хворих, на наш погляд, може бути викликане як неадекватним дренуванням, так і неефективною роботою дренажів та системи активної аспірації, раннім видаленням верхнього дренажу.

Для того щоб уникнути подібного ускладнення необхідно виконувати адекватне дренування плевральної порожнини. Ми вважаємо принциповим дренування плевральної порожнини 32 - х точок при виконанні подібних оперативних утручань. Застосування різних варіантів аспіраційних систем. Видалення верхнього дренажу після повного розпрямлення легені та припинення його функціонування.

Гострий тромбоз підключичної вени в місці стояння підключичного катетера ускладнив післяопераційний період у 1 пацієнта, що переніс декортикацію легені з приводу неспецифічної емпієми плеври. Це ускладнення можливо як 3 причини неефективного догляду за підключичним катетером, його тривалого стояння, так і порушення згортаючої системи крові в післяопераційному періоді. До профілактичних заходів слід віднести ретельний догляд за підключичним катетером, його своєчасне видалення, своєчасний i динамічний контроль згортаючої системи крові, застосування антикоагулянтної терапії.

Рецидив емпієми відмічений у 1 хворого, на наш погляд може бути обумовлений вираженою мікробною ураженістю стінок плевральної порожнини та вісцелярної плеври при декортикації легені; стійкістю мікроорганізмів до антибактеріальної терапії, що проводилася; нерадикальним виконанням декортикації; не видаленням плеврального ексудату в післяопераційному періоді. Дотримання правил антисептики під час проведення активної аспірації $і$ плевральної пункції в післяопераційному періоді; суворе дотримання методики операції декортикації легені, адекватне передопераційне і післяопераційне лікування хворого, раціональне застосування антибактеріальних препаратів зменшує вірогідність рецидиву емпієми плеври. В даному випадку виконана була реторакотомія в цілях санації та повторна декортикація.

Розвиток або загострення гнійно-деструктивного процесу в легені на стороні операції, що відмічається в 2-х спостереженнях, може бути пов'язано з неадекватною передопераційною підготовкою, відсутністю санації трахеобронхіального дерева під час та після операції, неадекватною антибактеріальною і протизапальною терапією, нераціонально вибраним об'ємом хірургічного втручання. При виникненні важкої пневмонії на стороні операції проводиться інтенсивна терапія, спрямована на усі ланки патогенезу патологічного процесу. При неефективності лікування, погіршення стану хворого за рахунок наростаючої токсемії показано повторне оперативне втручання для видалення осередку інфекції.

Нагноєння післяопераційної рани відмічене у 1 хворого. Причиною цього ускладнення може бути недостатній гемостаз під час ушивання рани, травмування прилеглих до розрізу тканин ранорозширювачем, розвитком інфекції, що "дрімає", в м'яких тканинах в умовах гнійної операції. Профілактикою цього ускладнення $\epsilon$ ретельне пошарове ушивання рани 3 адекватним гемостазом, делікатна техніка використання торакального ранорозширювача без ушкодження довколишніх тканин. Раціональна антибіотикотерапія, застосування фізіотерапевтичного лікування на ранніх етапах. У цього хворого виконано розкриття гнійника м'яких тканин. Терапія була доповнена фізіотерапевтичним лікуванням, в комплекс консервативної терапії додані нестероїдні протизапальні препарати, застосовані антибіотики широкого спектру дії.

Висновки. При виконанні роботи нами було виділено три групи ускладнень після виконання декортикації легені, що виникли в ранньому післяопераційному періоді: 1) ускладнення, що пов’язані з технікою проведення операції та наркозу; 2) ускладнення, що пов'язані 3 неефективним проведенням комплексної терапії в післяопераційному періоді; 3) поєднані ускладнення.

Проведення комплексної терапії в передопераційному і післяопераційному періоді 3 урахуванням порушень функцій органів і систем організму, виконання декортикації легені під візуальним контролем, проведення адекватної вентиляції легені під час операції, застосування різних аспіраційних режимів плеврального вмісту, рання санація трахеобронхіального дерева і активізація хворих після операції дозволяє попереджувати розвиток ускладнення у даної групи хворих. 


\section{ЛІТЕРАТУРА}

1. Reichert M. et al. Stage-directed therapy of pleural empyema //Langenbecks Arch Surg. - 2016. - Vol. 401. - P. 1-12.

2. Chen-Hao Hsiao, Ke-Cheng Chen, Jin-Shing. Modified singleport non-intubated video-assisted thoracoscopic decortication in high-risk parapneumonic empyema patients // L. Ferreiro Surg Endosc.2016. - Vol. 30 - P. 5164-5167.

3. Abhishek Biswas et al. Management of chronic empyema with nexpandable lung in poor surgical risk patients using an empyema tube // Lung India. - 2016. - N 33, - P. 267-271.

4. Kondov G. et al. Analysis of lung function test in patients with pleural empyema treated with thoracotomy and decortication //Prilozi. - 2011. - P. 259-271.

5. Опанасенко М. С., Терешкович О.В., Сірик О. О. та ін. Досвід застосування різних методик плевректомії з декортикацією легені при лікуванні фтизіопульмонологічних захворювань // Укр. пульмонол. журн. - 2011. - С. 49-52

6. AdIer R.H., Plaut M.E. Post-pneumonectomy empyema // Surgery. - 1999. - Vol. 71. - № 2. - P. $210-214$.

7. Cowen M.E., Johnston M.R. Thoracic empyema: causes, diagnosis, and treatment // Compr. Ther. - 1998. - № 10. - P. 40-45.

8. Hermann J.D., Fichtner K., Velanovich V., Cavanaugh D. Parapneumonic pleural effusions and empyemas: a plea for early drainage// Mil. Med. - 1999. - № 12. - P. 681-682.

9. Potzger T. et al. Decortication in Pleural Empyema: Reasonable Effects on Lung Function // Zentralbl Chir. - 2016. - Vol. 141. - P. 18-25.

10. Management of empyema thoracis in children: tube thoracostomy versus early decortication. / Department of Paediatric Surgery, Bahawal Victoria Hospital Bahawalpur // Current Opinion in Pulmonary Medicine. 2011. - Vol. 17 - P. 255-259. 